\title{
Assessment of Growth Performance of Acacia catechu
}

\author{
Pankaj Jha ${ }^{1}$, Ram Asheshwar Mandal ${ }^{2 *}$ \\ ${ }^{I}$ Department of Forest and Soil Conservation \\ ${ }^{* 2}$ Schools of Environmental Science and Management
}

\begin{abstract}
*Corresponding Author: Ram Asheshwar Mandal, Ph.D Scholar, School of Environmental Science and Management, Nepal, Email: ram.mandal@gmail.com
\end{abstract}

\begin{abstract}
Growth performance of any tree species is a major parameter to determine the felling rotation of that species. In Nepal, the growth performance of the Acacia catechu has not been assessed so far. Thus, this study was objectively carried out to assess the mean annual volume growth according to blocks and provenances. The Breeding Seed Orchard of Siraha district was selected for the study site. Both primary and secondary data were collected. The diameters and heights were measured using Diameter tape, Abney's level and linear tape. Total enumeration was done to collect the data so altogether 2520 plants were measured. The collected data were analyzed using descriptive and inferential statistics. The average volume in 2018 was found to be highest in Block D with $0.0186 \mathrm{~m}^{3}$ and lowest in Block A with $0.0130 \mathrm{~m}^{3}$. The mean annual volume increment was found to be highest in Block D i.e. $0.0031 \mathrm{~m}^{3}$ in 2018 and lowest in Block A i.e. $0.0022 \mathrm{~m}^{3}$. Here, the mean annual volume increment was found to be higher in 2018 as compared to 2016. The average volume of A. catechu was the highest around $0.0072 \mathrm{~m}^{3}$ in 2016 of Dhanusha (Dharapani) while it was the highest around $0.0191 \mathrm{~m}^{3}$ in 2018 of Dhading (Benighat) provenance. It was the highest mean annual volume increment $0.0018 \mathrm{~m}^{3}$ of Dhanusha (Dharapani) provenance in 2016 while it was the highest mean annual increment about 0.0032 in Sunsari (Parkashpur) prominence in 2018. The growth performance of this species will be useful to determine the rotation.
\end{abstract}

Keywords: Breeding Seed Orchard, Provenance, Mean Annual Increment

\section{BACKGROUND}

Forests are the valuable natural resources in Nepal. The forest cover in Nepal was around $45.5 \%$ which was reduced to $39.6 \%$ in 1994 (DFRS, 1999). With active participation of various organizations and nature conversationalist, forest covers have once again increased to $44.74 \%$ (DFRS/FRA, 2014). According to forest resource assessment (FRA, 2014), there is an increase of forest area by 5\% between 20 years period from 1990s. The MoEST (2008) has estimated that over $28 \%$ of the lands in Nepal are in degraded condition. It would be wise to select a native or naturalized species for the rehabilitation of degraded sites in mid-hills (Jha et al., 2013).

Acacia catechu is one of the very few species which grows well in the degraded lands and could be very useful for the community plantations in Nepal. It is a useful multi-purpose tree producing fuel wood, small timber and fodder which is very popular among the local people in Terai region (Thapa, 2004). The most important commercial products from Acacia catechu are Kathha and Cutch. Katha is mainly used for chewing with betal nut and pan, and also have medicinal and pharmacological use whereas the bi-product cutch used in tanning and dyeing ships (Jackson 1994).

Growth performance of any tree species is a major parameter to determine the felling rotation of that species (Thapa and Gautam, 2005, Onefeli and Adesoye, 2014). At the same time, the species wise growth performance varies according to its inherent quality obtained by its parent as well as the site quality and microclimate. Acacia catechu is planted in the Breeding Seed Orchards (BSOs) of Mirchaiya, Siraha Nepal (TISC, 2011 and 2012).

\section{Materials AND Methods}

\subsection{Study Area}

After discussion with Forest Silviculture Division staffs and analysis of different Breeding Seed Orchards (BSOs) records available at FSD (2015), BSO was selected from Siraha district for study. The BSO at Siraha district, Nepal was selected because it is one of the important site which was 
established with Randomized Block Design (RBD). The BSO was established in 2012 A.D. After the establishment of BSO, different silvicultural operations like weeding, cleaning, thinning, pruning were carried out. The first thinning was done after four years of establishment i.e.2016 A.D.

The information about the selected BSO is shown in following table 1 and figure 1:

Table1. The Information about Selected BSO

\begin{tabular}{|c|c|c|c|c|c|c|c|}
\hline BSO/Spp & Area ha & $\begin{array}{c}\text { Total } \\
\text { provenance }\end{array}$ & Seedling & $\begin{array}{c}\text { No. of } \\
\text { Blocks }\end{array}$ & $\begin{array}{c}\text { Total Seedling } \\
\text { Planted }\end{array}$ & Spacing & $\begin{array}{c}\text { Est. } \\
\text { Date }\end{array}$ \\
\hline $\begin{array}{c}\text { Acacia } \\
\text { catechu }\end{array}$ & 1 & 30 & 21 & 4 & 2520 & $1.5 \mathrm{~m} \mathrm{X} \mathrm{1.5m}$ & $2012 \mathrm{AD}$ \\
\hline
\end{tabular}

Plants were marked before measurement and also tied with red ribbon. As the plants were measured the ribbon was removed to avoid the repetition.
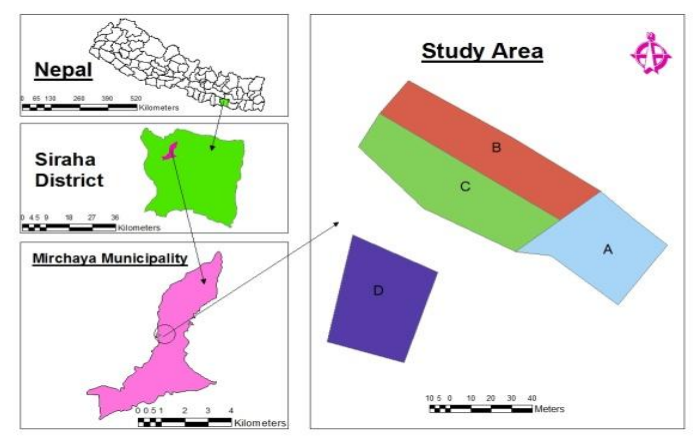

Figure1. Map of Study Area

\subsection{Data Collection}

Both primary and secondary data were collected. The primary data was collected from the field measurement. Total enumeration was done to collect the data so diameter and height of total 2520 plants were measured using D tape, Abney's level and simple tape (Chaturbedi and Khanna, 1982). The secondary information was gathered from the available records from department of forest. The secondary information included the plantation time, seed sources and previous measurements. In addition, the literature review, various publications of Ministry of Forest and Soil Conservation, Department of Forests, Department of Research and Survey and other related literature (published and unpublished) were consulted during this study.

\subsection{Data Analysis}

The data collected from different sources were processed, tabulated and analyzed qualitatively as well as quantitatively. Quantitative data was analyzed using descriptive statistics such as percentage, mean, frequency distribution, table, graphics etc. whereas qualitative data was analyzed in descriptive manner.

The Volume and mean annual volume increment were calculated using the measured records of diameter and height. The following formulae were used for the quantitative analysis.

Volume Calculation

$$
\text { Volume }(V)=\left(\frac{\pi \mathrm{d}^{2}}{4} * \text { Height } * \text { form factor }\right) / 10000
$$

Where, $\mathrm{V}=$ Volume in $\mathrm{m}^{3}, \mathrm{~d}=$ diameter in $\mathrm{cm}$

Mean Volume (MV) and Mean Annual Volume Increment (MAVI) $=$ MV/Age of tree

\section{RESULTS AND DISCUSSION}

\subsection{Mean Volume Growth of Acacia Catechu in Different Blocks}

The table shows that, the average volume of Acacia catechu before thinning was found to be highest in Block D i.e. $0.0061 \mathrm{~m}^{3}$ and lowest in Block B i.e. $0.0045 \mathrm{~m}^{3}$. Similarly, the average volume in 2018 was found to be highest in Block D i.e. $0.0186 \mathrm{~m}^{3}$ and lowest in Block A i.e. $0.0130 \mathrm{~m}^{3}$. The difference in the average volume was found highest in block D i.e. $0.0125 \mathrm{~m}^{3}$ and the lowest in block A i.e. $0.0081 \mathrm{~m}^{3}$. 
Likewise, the mean annual volume increment (MAVI) before thinning was found to be highest in Block D i.e. $0.0015 \mathrm{~m}^{3}$ and lowest in Block B i.e. $0.0011 \mathrm{~m}^{3}$. The mean annual volume increment in 2018 was found to be highest in Block D i.e. $0.0031 \mathrm{~m}^{3}$ and lowest in Block A i.e. $0.0022 \mathrm{~m}^{3}$. Here, the mean annual volume increment was found to be higher in 2018 as compared to 2016 (Table 2).

Table2. Mean Volume Growth of Acacia Catechu in Different Blocks

\begin{tabular}{|c|c|c|c|c|c|c|}
\hline Block & $\begin{array}{c}\text { Avg.vol. } \\
\left(\mathrm{m}^{3}\right) \text { in } 2016\end{array}$ & $\begin{array}{c}\left.\text { Avg.vol.(m }{ }^{3}\right) \text { in } \\
2018\end{array}$ & Difference & $\begin{array}{c}\text { Difference } \\
\% \\
\end{array}$ & $\begin{array}{c}\text { MAVI }\left(\mathrm{m}^{3}\right) \\
\text { in } 2016\end{array}$ & $\begin{array}{c}\text { MAVI }\left(\mathrm{m}^{3}\right) \text { in } \\
2018\end{array}$ \\
\hline A & 0.0050 & 0.0130 & 0.0081 & 161.1405 & 0.0012 & 0.0022 \\
\hline $\mathrm{B}$ & 0.0045 & 0.0144 & 0.0099 & 218.3764 & 0.0011 & 0.0024 \\
\hline $\mathrm{C}$ & 0.0050 & 0.0160 & 0.0110 & 219.2695 & 0.0013 & 0.0027 \\
\hline $\mathrm{D}$ & 0.0061 & 0.0186 & 0.0125 & 204.5835 & 0.0015 & 0.0031 \\
\hline
\end{tabular}

One way ANOVA Test for comparing carbon growth in Acacia catechu in Different blocks and Tukey's B Post hoc test shows that there is no significant difference in volume growth of Acacia catechu of different provenances y at $95 \%$ confidence level.

\subsection{Mean Volume Growth of Acacia Catechu According to Provenances (Different Sites)}

The average volume of A. catechu was the highest around $0.0072 \mathrm{~m}^{3}$ in 2016 of Dhanusha (Dharapani) while it was the highest around $0.0191 \mathrm{~m}^{3}$ in 2018 of Dhading (Benighat) provenance. It was the highest mean annual volume increment $0.0018 \mathrm{~m}^{3}$ in 2016 of Dhanusha (Dharapani) provenance while it was the highest mean annual increment about 0.0032 Sunsari (Parkashpur) provenances (Table 3).

Table3. Growth of Acacia Catechu of Different Provenance

\begin{tabular}{|c|c|c|c|c|c|c|}
\hline District/Place (Provenance) & $\begin{array}{c}\text { Avg. vol. } \\
\left(\mathrm{m}^{3}\right) \text { in } \\
2016\end{array}$ & $\begin{array}{c}\text { Avg.vol. } \\
\left(\mathrm{m}^{3}\right) \text { in } \\
2018\end{array}$ & Difference & $\begin{array}{c}\text { Difference } \\
\%\end{array}$ & $\begin{array}{l}\text { MAVI } \\
\left(\mathrm{m}^{3}\right) \text { in } \\
2016\end{array}$ & $\begin{array}{c}\text { MAVI } \\
\left(\mathrm{m}^{3}\right) \text { in } \\
2018\end{array}$ \\
\hline Jhapa (Suranga) & 0.0057 & 0.0176 & 0.0119 & 208.772 & 0.0014 & 0.0029 \\
\hline Ilam (Danabari) & 0.0049 & 0.0115 & 0.0066 & 134.694 & 0.0012 & 0.0019 \\
\hline Sunsari (Parkashpur) & 0.0056 & 0.0136 & 0.008 & 142.857 & 0.0014 & 0.0023 \\
\hline Saptari (Mahuliya) & 0.0052 & 0.0192 & 0.014 & 269.231 & 0.0013 & 0.0032 \\
\hline Siraha (Bandipur) & 0.0051 & 0.016 & 0.0109 & 213.726 & 0.0013 & 0.0027 \\
\hline Siraha (Mirchaiya) & 0.0043 & 0.0147 & 0.0104 & 241.861 & 0.0011 & 0.0025 \\
\hline Siraha (Phulbariya) & 0.0057 & 0.0132 & 0.0075 & 131.579 & 0.0014 & 0.0022 \\
\hline Siraha (Chaurahwa) & 0.0045 & 0.0133 & 0.0088 & 195.556 & 0.0011 & 0.0022 \\
\hline Dhanusha (Dhanushadham) & 0.0054 & 0.0162 & 0.0108 & 200.00 & 0.0014 & 0.0027 \\
\hline Dhanusha (Godara) & 0.0041 & 0.0135 & 0.0094 & 229.268 & 0.001 & 0.0023 \\
\hline Dhanusha (Umaprempur) & 0.0055 & 0.0162 & 0.0107 & 194.546 & 0.0014 & 0.0027 \\
\hline Dhanusha (Dharapani) & 0.0072 & 0.0161 & 0.0089 & 123.611 & 0.0018 & 0.0027 \\
\hline Mahottari (Bardibas) & 0.0048 & 0.0164 & 0.0116 & 241.667 & 0.0012 & 0.0027 \\
\hline Sarlahi (Hariwan) & 0.0058 & 0.0177 & 0.0119 & 205.172 & 0.0015 & 0.003 \\
\hline Rautahat (Chandranigahpur) & 0.0061 & 0.014 & 0.0079 & 129.508 & 0.0015 & 0.0023 \\
\hline Rautahat (Gaidatar) & 0.006 & 0.0152 & 0.0092 & 153.333 & 0.0015 & 0.0025 \\
\hline Bara (Ratanpur) & 0.0049 & 0.0168 & 0.0119 & 242.857 & 0.0012 & 0.0028 \\
\hline Dhading (Salyantar) & 0.0054 & 0.0138 & 0.0084 & 155.556 & 0.0014 & 0.0023 \\
\hline Dhading (Gajuri) & 0.0039 & 0.0164 & 0.0125 & 320.513 & 0.001 & 0.0027 \\
\hline Dhading (Galaudi) & 0.0059 & 0.0139 & 0.008 & 135.593 & 0.0015 & 0.0023 \\
\hline Dhading (Kumpur) & 0.0056 & 0.0152 & 0.0096 & 171.429 & 0.0014 & 0.0025 \\
\hline Dhading (Benighat) & 0.0049 & 0.0191 & 0.0142 & 289.796 & 0.0012 & 0.0032 \\
\hline Dhading (Salangaghat) & 0.0048 & 0.0146 & 0.0098 & 204.167 & 0.0012 & 0.0024 \\
\hline Nawalparasi (Bardaghat) & 0.0066 & 0.0173 & 0.0107 & 162.121 & 0.0017 & 0.0029 \\
\hline Nawalparasi (Triveni) & 0.0058 & 0.0177 & 0.0119 & 205.172 & 0.0015 & 0.003 \\
\hline Rupandehi (Tamnagar) & 0.0045 & 0.0166 & 0.0121 & 268.889 & 0.0011 & 0.0028 \\
\hline Rupandehi (Ranibagiya) & 0.0035 & 0.0145 & 0.011 & 314.286 & 0.0009 & 0.0024 \\
\hline Rupandehi (Murgiya) & 0.0044 & 0.0153 & 0.0109 & 247.727 & 0.0011 & 0.0026 \\
\hline Kapilbastu (Chandrauta) & 0.0046 & 0.0184 & 0.0138 & 300 & 0.0012 & 0.0031 \\
\hline Kanchanpur (Chadanidodhara) & 0.0056 & 0.0133 & 0.0077 & 137.5 & 0.0014 & 0.0022 \\
\hline
\end{tabular}

Note: Avg. Vol. Indicates Average Volume in Table 
Volume growth depends up on the growth of height and diameter of the plants. In 72 months period, the volume growth of Acacia catechu of 30 different provinces was recorded 0.001 to $0.003 \mathrm{~m}^{3}$. The site quality, damage, light condition (open, shade, hinder), local operations, diseases effects are main causes of variation of growth performance of plants (Karlen et al., 1997, Goel and Singh 2008, Deve and Parthiban, 2014). In addition, the moist condition also affects the growth of the plants (Hunter, 2000, Moni et al., 2014). The study Growth Performance of Native Tropical Tree Species on a Coal Mine Spoil on Singrauli Coalfields, India done by Singh et al. (2009), resulted that, 'the height, diameter and volume of 2-years and 9 months-old tree species ranged between 1.59 to $4.25 \mathrm{~m}, 4.41$ to $9.29 \mathrm{~cm}$ and 3503 to $36238 \mathrm{~cm}^{3}$, respectively.

\section{CONCLUSION AND RECOMMENDATION}

The mean annual volume increment (MAVI) before thinning was found to be highest in Block D and lowest in Block B. The average volume of A. catechu was the highest around in 2016 of Dhanusha (Dharapani) but it was highest in 2018 of Dhading (Benighat) provenance. Similarly, the highest mean annual volume increment was in 2016 of Dhanusha (Dharapani) provenance while it was the highest mean annual increment about Sunsari (Parkashpur) prominence. Therefore, these provenances are very appropriate for seed production of $A$. catechu.

Such types of research showing the growth performance should be continued to find growth performance upto maturity.

\section{REFERENCES}

[1] Chaturbedi A. N. and Khanna L. S. 1982. Forest Mensuration. International Book Distributors 9/3 Rajpur Road (First floor) Dehradun- 248001 (India)

[2] Deve Dhixya K.R. and Parthiban K. T. 2014. Growth performance and variability of Dalbergia sissoo Roxb. Clones. Electronic Journal of Plant Breeding, 5(2): 317-321. DOI: http://sites.google.com/site/ ejplantbreeding. Cited on: 11/21/2015:

[3] DFRS. 1999. Forest Resources of Nepal, Department of Forest Research and Survey. Publication No 74, Kathmandu, Nepal.

[4] Drechsel P. and Zech W. 1991. Foliar nutrient levels of broad-leaved tropical trees: a tabular review. Plant Soil 131 (1), 29 \pm 46.

[5] DFRS/FRA. 2014. Terai Forests of Nepal. Forest Resource Assessment Nepal, Department of Forest Research and Survey, Kathmandu, Nepal. IXp

[6] FSD. 2015. Yearly Progress Report 2071. Forest Silviculture Division Department of Forest, Babarmahal Kathmandu.

[7] Goel V.L. and Singh B. 2008. Growth and Productivity potential of Dalbergia sisooin Short Rotation Coppice System in Sodic Soil. Indian Journal of Forestry, 31(4): 491-499.

[8] Hunter I. 2000. Above ground biomass and nutrient uptake of three tree species (Eucalyptus camaldulensis, Eucalyptus grandis and Dalbergiasissoo) as affected by irrigation and fertilizer, at 3 years of age, in southern India. Forest Ecology and Management, 144 (1 - 3): 189 - 200

[9] Jackson J.K.1994. Manual of Afforestation in Nepal, Volume 1 and II Forest Research and Survey Department, Kathmandu.

[10] Jha RK.,Baral SK., Aryal R. and Thapa HB. 2013. Restoration of degraded sites with suitable tree species in the Mid-hills of Nepal, BankoJankari23 (2): 3-13.

[11] Moni R., Das KS. And Nath AJ. 2014. Comparative study on growth performance of two shade trees in tea agroforestry system. Department of Ecology and Environmental Science, Assam University, Silchar-788 011, India.

[12] Karlen, D.L., Mausbach M.J., Doran J.W., Cline R.G., Harris R.F., and Schuman G.E., 1997. Soil quality: A concept, definition, and framework for evaluation. Soil science Society, Kathmandu.

[13] MoEST. 2008. State of the Environment (Agriculture, Forest and Biodiversity). Ministry of Science and Technology, Singh Durbar Kathmandu.

[14] Onefeli AO and Adesoye PO. 2014. Early Growth Assessment of Selected Exotic and Indigenous Tree Species in Nigeria. South-east Eur for 5 (1): 45-51. DOI: http://dx.doi.org/10.15177/seefor.14-06. Cited on: $11 / 21 / 2015$

[15] Singh R., Pal RS. and Banerjee S. 2009. Growth Performance of Multipurpose Tree Species In Degraded Land Under Agroforestry Practices. Journal of Tropical Forestry vol.25 (I and II) .Tropical Forest Research Institute, Jabalpur, India. 
[16] Thapa HB. 2004. Early growth, thinning yiled and estimated biomass of standing trees of Dalbergia sissoo Roxb. In the eastern Terai, Nepal. Banko Janakari 14(1):31-40.(2004)

[17] Thapa HB and Gautam SK. 2005. Growth performance of Tectona grandis in the western Terai of Nepal. BankoJanakari, Vol.15, No.2 (2005).

[18] TISC 2011. Species Leaflests for 131Woody Species 2011. Tree Improvement and Silviculture Component, Department of Forest, Hattisar, Kathmandu.

[19] TISC. 2012. An Overview of TISC 2012. Tree Improvement and Silviculture Component, Department of Forest, Hattisar, Kathmandu.

Citation: Pankaj Jha, Ram Asheshwar Mandal" Assessment of Growth Performance of Acacia Catechu' International Journal of Advanced Research in Botany (IJARB), vol. 5, no. 1, pp. 34-38, 2019. http://dx.doi. org/10.20431/2455-4316.0501005

Copyright: (C) 2019 Authors. This is an open-access article distributed under the terms of the Creative Commons Attribution License, which permits unrestricted use, distribution, and reproduction in any medium, provided the original author and source are credited. 